\title{
Meat Pet Snacks By Containing Encapsulated Saccharomyces Boulardii
}

\author{
Sheila Baroncello, Nathalia Turkot Candiago, Jane Mary Lafayette Neves Gelinski, Vinícius Caliari \\ and César Milton Baratto
}

\begin{abstract}
The global trend is to minimize losses by using by-products from slaughterhouses as part of sustainable food production, both for human and animal consumption. Another growing trend is the development of pet feed with properties beneficial to the consumer's health. Another trend is the development of feeds with beneficial properties for the health of animals. Thus, the objective of this study was to use mechanically separated pork meat and by-products (trachea) to produce a pet snack containing the encapsulated probiotic yeast Saccharomyces boulardii. The experimental design followed in three main stages: 1) development of a pet pork snack (trachea snack); 2) microencapsulation of the probiotic and insertion in the pet snack; 3) Shelf life evaluation and palatability of the pet snack. $S$. boulardii was microencapsulated by extrusion technique and remained viable after 120 days of shelf life. The acceptability index of the probiotic pet snack was $77.8 \%$. We concluded that $S$. boulardii provides beneficial probiotics characteristics to pet snack whose composition has high levels of protein $(\mathbf{5 7 . 5 0 \%})$. Thus, the novel pet product has a good appeal to the functional products market.
\end{abstract}

Index Terms - Encapsulation, Extrusion, Pet feed market, Probiotic, Yeast.

\section{INTRODUCTION}

The pet food market is booming. The U.S. is by far the largest pet food market [38]. However, with 54.2 million dogs and 23.9 million cats, Brazil is the second largest market for pet products in the world, reaching 20.3 billion in 2018 [1]. The nutrition of dogs and cats has for some time been equated with human nutrition, with the incorporation of functional substances in food [10]. The market has been adapting to the needs and creating new specific products and services of the most varied formats and prices, all to keep the animal within the family reality [40]. In this sense, important trends [55], [8] are established in the sector of products aimed at domestic animals:

Published on July 11, 2020.

S. Baroncello, NB-University of West of Santa Catarina, Brazil.

(e-mail: Sheila.baroncello@gmail.com).

N. T. Candiago, NB-Unoesc, Brazil.

(e-mail: nathalia.turkot@hotmail.com).

J. M. L. N. Gelinski., NB-Unoesc, Brazil.

(corresponding e-mail: jgelinski@yahoo.com.br)

V. Caliari, Estação Experimental de Videira, Brazil.

(e-mail: caliari@epagri.sc.gov.br)

C. M. Baratto, NB-Unoesc, Brazil

(e-mail: cesar.baratto@unoesc.edu.br).
1) segmentation: product that meets specific needs by: stage of life (puppy, adult, senior), specific diets, size of the animal (small, medium, large), breed, among others;

2) premium market: increasingly noble and specific products;

3) humanization: attention to the close relationship between dog and owner;

4) practicality of the food: pet owners have an arduous work routine and seek dry, practical foods, beneficial for the consumption and health of their animals;

5) market distribution: the ease of access, the increase in logistics networks allows for a closer relationship between suppliers, distributors and consumers, due to the increasing insertion of products in regional markets.

6) health and well-being: product with functionality: prebiotics, probiotics and symbiotics.

Probiotics are beneficial microorganisms, supporting animal health that provide greater longevity and decrease the risk of developing diseases throughout life; they are also alternatives to the treatment and prevention of diarrhoea [52], [6], [33], [19].

Within the group of beneficial microorganisms, the probiotic yeast Saccharomyces boulardii, has been widely used for the treatment of diarrhoea and inflammatory conditions of the gastrointestinal tract [50], [30]. Clinical trials of $S$. boulardii have shown probiotic activity of this yeast, as it is considered a probiotic supplement to support gastrointestinal health, since it prevents intestinal infections caused by different pathogens [59].

In addition to being effective against infections caused by pathogenic bacteria, $S$. boulardii has an anti-secretory and anti-inflammatory effect [47], antibacterial and antimutagenic action [56], [36]. When ingested, yeast is not established in the gastrointestinal tract, however, it is very well absorbed by the organism, remaining viable during treatment [44], [54]. Briefly, the mechanisms of action of $S$. boulardii can be classified into three points: luminal action, trophic action, and anti-inflammatory effects on the intestinal mucosa [41].

Various studies [4], [21], [42] have shown that to maintain the probiotic potential of beneficial microorganisms in the host organism, encapsulation is an alternative of multiple applications. It is a technique in which the encapsulated is protected from the action of the gastrointestinal tract, with release in a controlled manner and under conditions specific [29].

In the present study, $S$. boulardii was encapsulated to form a snack because the target audience consists of dogs and cats whose stomach $\mathrm{pH}$ is around $2.5-3$ and between $5.7-6.4$ in the intestine [20]. Microencapsulation is a way 
of ensuring that the yeast during consumption reaches the intestine in a viable way and tolerates sudden changes in $\mathrm{pH}$, without undergoing major changes [2]. Therefore, in the present study, by-products of swine slaughterhouses were used to develop a meat snack for dogs and cats containing encapsulated $S$. boulardii. In addition, we seek to contribute to the sustainable development of the food production chain by providing a product with probiotic properties and aimed at the pet market. Thus, the aim was to use mechanically separated pork meat and by-products (trachea) to produce a pet snack containing the encapsulated probiotic yeast $S$. boulardii.

\section{MATERIAl AND Methods}

\section{A. Probiotic yeast viability tests}

The viability of the yeast Saccharomyces boulardii obtained in lyophilized form (COANA-Import and Export Ltd) was initially assessed by counting in a Neubauer chamber (New Optik) from dilution (1/10) of the sample in $0.85 \%$ saline solution, and analysis by optical microscopy (Nikon Eclipse E100, obj.400x). Differentiation of live cells from dead cells was carried out with the $2 \%$ Trypan blue dye (Laborclin Brazil). The number of viable cells per $\mathrm{mL}$ was obtained with equation 1 :

$$
\begin{aligned}
& n^{\circ} \text { of cell per } m L= \\
& \frac{\text { total number of cells }}{\text { number of quadrant counted }} \text { dilution factor } \times 10000
\end{aligned}
$$

\section{B. Evaluation of the yeast under different growth conditions}

\section{Temperature and oxigen}

To assess the best temperature and condition of yeast development, it was inoculated in Yeast Extract and Glucose (YEG) broth by using $5 \mathrm{~g} / \mathrm{L}$ of yeast extract (Bacto TM) and $20 \mathrm{~g} / \mathrm{L}$ of glucose (Synth Brazil). The incubation was carried out at different temperatures: $25^{\circ} \mathrm{C}, 28^{\circ} \mathrm{C}, 35^{\circ} \mathrm{C}$ and $37^{\circ} \mathrm{C}$, for 48 hours in aerobic and anaerobic conditions.

Salinity Test. Aliquots of $S$. boulardii cultures previously grown in YEG broth for 24 hours were subjected to solutions with different concentrations of salt $(\mathrm{NaCl}): 1 \%$, $1.5 \%, 2 \%, 2.5 \%$ and $3 \%$, incubating at $25^{\circ} \mathrm{C}$ for 24 hours.

$\mathrm{pH}$ test. To assess the degree of acidity that the probiotic yeast is capable of withstanding, the YEG broth was used by changing the $\mathrm{pH}$ with a $7 \mathrm{M} \mathrm{HCl}$ solution, (Quimis ${ }^{\circledR}$, São Paulo) to: $1.5 ; 2 ; 2.5 ; 3 ; 3.5 ; 4$ and 4.5 . The test solutions were incubated at $25^{\circ} \mathrm{C}$ for 72 hours.

2. Growth curve assessment

To evaluate the number of viable cells, a yeast culture was performed in YEG broth and incubated at $25^{\circ} \mathrm{C}$ for 72 hours in aerobic conditions. After that, an aliquot was inoculated into Erlenmeyer containing YEG broth for a final dilution of $1: 100$, after transferring it to a shaker incubator (Nova Ética, São Paulo) at $200 \mathrm{rpm}, 25^{\circ} \mathrm{C}$ for 24 hours. At 2-hour intervals, a spectrophotometer reading (Pró-Análise, Brazil) was performed at $\lambda 600 \mathrm{~nm}$. At the same time, inoculations of each dilution were performed using the spread plate technique in YE agar plates and incubating at $25^{\circ} \mathrm{C}$ by until 72 hours.
The total dry mass of the sample was evaluated by gravimetric analysis. About $20 \mathrm{~mL}$ of sample obtained under the same conditions as above were filtered through a cellulose acetate membrane $(0.22 \mu \mathrm{m})$ previously dried in a drying oven (Gigante, São Paulo) at $60{ }^{\circ} \mathrm{C}$ until constant mass. Then, after filtration, the membrane containing the cell mass was kept at $65^{\circ} \mathrm{C}$ for 1 hour until an inert weight was obtained.

\section{Development of meat snack for pets}

\section{Feedstock}

The raw material of animal origin came from establishments registered with the Federal Inspection System of Brazil. The samples were transported in thermal boxes (maximum temperature of $4{ }^{\circ} \mathrm{C}$ ) and product temperature monitoring at reception. For the development of the meat product, the following were used: a) swine and gut trachea; b) lyophilized $S$. boulardii. The storage took place at temperatures of $-20{ }^{\circ} \mathrm{C}$ until the analysis and release for processing.

\section{Standardization and dehydration}

After cleaning step to remove excess fats and meat, the trachea was cut into $1 \mathrm{~cm}$ pieces. Dehydration was carried out in an oven with air circulation for 7 hours at $68^{\circ} \mathrm{C}$.

\section{Snack filling}

The filling was produced with mechanically separated meat (MSM, 37.0\%), wheat flour (34.0\%), water (ice, $16.5 \%)$, rice flour $(5.0 \%)$ and animal fat $(5.0 \%)$, sodium chloride $(1.8 \%)$, bi-calcium tripolyphosphate $(0.5 \%)$, ascorbic acid $(0,2 \%)$, sodium nitrite $(0,015 \%)$ and Butylated hydroxytoluene (BHT, 0,011\%). The percentages were defined based on the human food legislation according to the Health Surveillance Agency and the Ministry of Agriculture, Livestock and Supply of Brazil [13].

\section{Processing and cooking}

The ingredients were separated and processed in a cutter according to the sequence:

1) beat the MSM made up entirely of chilled kids and half of the curing salt until they were broken up;

2) Add half of the ice ( $8.6 \%$ ), beat again;

3) Place the fat and the rest of the spices and beat until the whole mixture is diluted;

4) Add the remaining ice and flour, mix well.

The finished filling was applied inside each trachea unit. The stuffed tracheas were sent to a preheated oven following the cooking times/temperature, as described in Table I.

\begin{tabular}{ccc}
\multicolumn{3}{c}{ TABLE I: Cooking Time Of Meat Snack (Trachea) } \\
\hline Order & $\begin{array}{c}\text { Time } \\
(\mathrm{min})\end{array}$ & Temperature ${ }^{\mathrm{o}} \mathrm{C}$ \\
\hline $1^{\mathrm{a}}$ & 30 & 55 \\
$2^{\mathrm{a}}$ & 45 & 65 \\
$3^{\mathrm{a}}$ & 45 & 75 \\
$4^{\mathrm{a}}$ & 15 & 85 \\
$5^{\mathrm{a}}$ & 15 & 95 \\
$6^{\mathrm{a}}$ & 30 & 105 \\
$7^{\mathrm{a}}$ & 30 & 115 \\
\hline
\end{tabular}

\section{Probiotic application - microencapsulation}

Three methods of encapsulating $S$. boulardii were used. The performance of each test was based on the total viable 
cells in standard yeast agar $(\mathrm{CFU} / \mathrm{mL})$ as well as already described [18].

Methodology 1. S. boulardii culture was grown in YEG broth: from a 72 -hour culture at $25^{\circ} \mathrm{C}$ in YEG broth under aerobiosis. an aliquot was placed in Eppendorf tubes for centrifugation (Quimis ${ }^{\circledR}$, São Paulo) for 10 minutes, $4^{\circ} \mathrm{C}$, 7590 RCF. Then, the supernatant was discarded and the pellet washed with distilled water. The procedure was performed twice. To the final pellet, $500 \mu \mathrm{L}$ of glycerine (Dinâmica ${ }^{\circledR}$ São Paulo) and $500 \mu \mathrm{L}$ of $2 \%$ sodium alginate solution (Dinâmica ${ }^{\circledR}$ São Paulo) were added, homogenizing the mixture and transferring to a $1 \mathrm{~mL}$ sterile syringe (26G1 needle/2 13x0.45). From 0.1M CaCl2 solution (Dinâmica ${ }^{\circledR}$, São Paulo) the mixture was dripped using the extrusion technique, stirring occasionally, forming the microcapsules instantly which were left in contact with the solution for 10 minutes. The microcapsules were filtered on filter paper and kept in cryovials with a 1:1 solution of sterile distilled water and YEG broth at $4^{\circ} \mathrm{C}$. Methodology 2. S. boulardii lyophilized with chitosan coverage: from $1000 \mathrm{mg}$ of lyophilized yeast powder $3.5 \mathrm{~mL}$ of glycerine and $3.5 \mathrm{~mL}$ of $2 \%$ sodium alginate solution were added. The mixture was homogenized and passed to a $20 \mathrm{~mL}$ sterile disposable syringe with an 18G1 $40 \times 1.2$ hypodermic needle (Injex, São Paulo), dripping in $0.1 \mathrm{M} \mathrm{CaCl} 2$ by extrusion and stirring eventually, keeping the microcapsules in contact with the solution for 10 minutes, following for filtration. In watch glass with chitosan powder (Vetec, Rio de Janeiro), the microcapsules were transferred and slightly agitated to form the protective chitosan barrier, followed by storage in cryovials at $4^{\circ} \mathrm{C}$.

Methodology 3. In $1500 \mathrm{mg}$ of lyophilized S. boulardii were added $3.5 \mathrm{~mL}$ of glycerine and $3.5 \mathrm{~mL}$ of $2 \%$ sodium alginate solution, homogenizing and transferring to a sterile $20 \mathrm{~mL}$ syringe with a 40X1 18G1 hypodermic needle. By using the extrusion technique, it was dripped into a $0.1 \mathrm{M}$ $\mathrm{CaCl} 2$ solution, stirring occasionally for 10 minutes. Then, the capsules were filtered and stored in cryotubes according to methodology 1.

\section{E. Viability of encapsulated yeast after action of gastric and intestinal juice}

To simulate the action in gastrointestinal transit and to evaluate the survival of $S$. boulardii in relation to $\mathrm{pH}$ changes, the procedure was carried out based on the simulation method proposed by [58]: gastric juice ( $\mathrm{pH} \mathrm{2):}$ $\mathrm{NaCl}$ 9g/L (Vetec, Rio de Janeiro), pepsin 3g/L (Vetec Rio de Janeiro). Intestinal juice ( $\mathrm{pH} 8$ ): $\mathrm{NaCl} 6.5 \mathrm{~g} / \mathrm{L} ; 0.835 \mathrm{~g} / \mathrm{L}$ $\mathrm{KCl}$ (Synth, São Paulo); 0.22 g/L CaCl2; NaHCO3 $1.386 \mathrm{~g} / \mathrm{L}$ (Vetec, Rio de Janeiro); pancreatin $1 \mathrm{~g} / \mathrm{L}$; bile salts $3 \mathrm{~g} / \mathrm{L}$ (Himedia ${ }^{\circledR}$, Brazil).

In a sterile plastic bag, $30 \mathrm{~mL}$ of gastric juice and three microcapsules were added, where it remained for 2 hours in a stomacher-type homogenizer with speed 1. In parallel, for each100 minutes aliquots of $100 \mu \mathrm{L}$ were removed and spread by spreading on plates of Sabouraud Dextrose agar (SD) (Acumedia ${ }^{\circledR}, \mathrm{USA}$ ). The incubation took place for 96 hours at $25^{\circ} \mathrm{C}$ in aerobiosis. The microcapsules were also transferred to $30 \mathrm{~mL}$ of intestinal juice for 45 minutes, and at times 20 and 45 minutes, using the inoculum on SD agar plates, according to the previous process.

\section{F. $\quad$ Microbiological evaluation and shelf-life}

The methodologies applied for microbiological analysis were carried out according to the provisions of Normative Instruction SDA No. 62, 26 August 2003, of the Ministry of Agriculture, Livestock and Supply [14].

To verify and guarantee the safety and hygiene of the raw material and the final product, a microbiological evaluation was carried out during the shelf life (5 months). Table II shows the analysis carried out according to the parameters considering the legislation for similar products, based on two microbiological criteria: Safety and Hygiene criteria.

TABLE II: MiCROBIOLOGICAL PARAMETERS DEFINED FOR EVALUATION
\begin{tabular}{cc} 
OF PET SNACK WITH PROBIOTIC Saccharomyces boulardii \\
\hline Criteria & Parameter \\
\hline Safety: & Salmonella sp. $/ 25 \mathrm{~g}^{*}$ \\
& Clostridium (reducing sulfite) at $46^{\circ} \mathrm{C}^{* *}$ \\
& Staphylococcus aureus ${ }^{*}$ \\
& Molds and Yeasts* \\
\hline Hygiene: & Aerobic Mesophiles \\
& Aerobic Thermophiles \\
& Saccharomyces boulardii \\
\hline
\end{tabular}

$*[12] ; * *[15]$

The culture media used in the analysis included: Tetrathionate broth (Acumedia ${ }^{\circledR}, \quad$ USA), Rappaport Vassiliadis broth (Acumedia ${ }^{\circledR}$, USA) and Hektoen-Enteric agar (HE) (Himedia ${ }^{\circledR}$, Brazil) for Salmonella sp., TSC agar for Clostridium reducing sulfite, Baird Parker for Staphylococcus aureus, Potato Dextrose (PDA) for molds and yeasts (Kasvi, Brazil), Plate Count agar for aerobic mesophilic or thermophiles (PCA), and YE agar with glucose (YEG) for $S$. boulardii. (Acumedia ${ }^{\circledR}, \mathrm{USA}$ )

\section{G. Physicochemical analysis}

The guarantee levels for products intended for animal feed must comply with the technical regulations of identity and quality issued by the Ministry of Agriculture, Livestock and Supply [16]. Pet food must have the following guarantees on their labels or packaging: Moisture (maximum), Crude Protein (minimum), Etheric Extract (minimum), Fiber Matter (maximum), Mineral Matter (maximum), Calcium (maximum) and Phosphorus (minimum) [13]. The analysis included: moisture, crude protein, ether extract, fibrous matter, mineral matter [35], Calcium [11], and Phosphorus [11].

\section{H. Palatability Analysis}

The palatability analysis with dogs was approved by the Ethics Committee on the Use of Animals of the Academic institution where the study was carried out and has received the acceptance number protocol no. 67/2018. The animals included in this study were $n=20$ dogs, males and females, adults, healthy of medium and small breeds staying in a clinic and inn for dogs. As an inclusion factor in the research, the animals needed to be at the ideal weight and a diet, as routine (feed and water). The animals were separated so that there was no interference among them; two meals a day were offered with a snack between them. The offer was repeated on a non-subsequent day for 7 days. The snack acceptance assessment was performed based on: if acceptance was immediate within $10 \mathrm{~min}$; if the animals 
presented voluntary consumption; if there was total consumption in 2 hours; if there were leftovers, (regret); what were the reactions presented. All relevant information was recorded in the period (animal behavior, food dispute, environment, contact with owners).

The palatability of the food was assessed based on the acceptance methods Equation 2 was used to calculate the product's Acceptability Index (AI):

$$
A I(\%)=\frac{A \times 100}{B}
$$

Where: $\mathrm{A}=$ average grade obtained for the product, and $\mathrm{B}=$ maximum grade given to the product [49]. AI with good repercussions has been considered $\geq 70 \%$ [26], [57].

\section{RESULTS AND DISCUSSION}

\section{A. Probiotic Yeast Viability Tests Under Different} Culture Conditions

The Table III shows that the best growth temperature for S. boulardii was $25^{\circ} \mathrm{C}$. However, data from other studies state that the ideal temperature for growth is $37^{\circ} \mathrm{C}$, which would be like body temperature [31], [24], [25].

$S$. boulardii behaved as an optional aerobic, growing normally both in the presence of oxygen and at low oxygen tension. Therefore, it can adapt according to the conditions of the environment [46].

In relation to the different concentrations of salt $(\mathrm{NaCl})$ to which it was submitted, the microorganism developed better at a concentration of $1 \%$, with an average cell density of $1.81 \times 10^{7}$ cells.mL $\mathrm{mL}^{-1}$ (Table III), meaning that a high concentration of salt is able to interfere with its growth.

Considering the best growth conditions tested, it was found that at $25^{\circ} \mathrm{C}$ in aerobic conditions by cultivation on SD / PDA agar plates the yeast reached $1.52 \times 10^{7} \mathrm{CFU} / 24$ hours. It was also estimated that each colony formed on a YEG agar plate can generate an average of $2.03 \times 10^{8}$ cells/mL / 24 hours (Fig.1). Gravimetric analysis resulted in a final dry mass of $0.2623 \mathrm{~g}$.

In relation to the $\mathrm{pH}$ there was a rapid multiplication of yeasts, reaching $6.78 \times 10^{7}$ cells. $\mathrm{mL}^{-1}$ at $\mathrm{pH} 3.5$ (Table III). A study by [27], presented very similar results when comparing a strain of Saccharomyces cerevisiae with $S$. boulardii, in which both were inoculated at different $\mathrm{pH}$ 's and, while $S$. cerevisiae showed a great decline in its development according to more acidic $\mathrm{pH}, S$. boulardii remained in equal growth until reaching $\mathrm{pH} 2$.

In relation to the $\mathrm{pH}$ there was a rapid multiplication of yeasts, reaching $6.78 \times 10^{7}$ cells. $\mathrm{mL}^{-1}$ at $\mathrm{pH} 3.5$ (Table III). A study by [27], presented very similar results when comparing a strain of Saccharomyces cerevisiae with $S$. boulardii, in which both were inoculated at different $\mathrm{pH}$ 's and, while $S$. cerevisiae showed a great decline in its development according to more acidic $\mathrm{pH}, \quad S$. boulardii remained in equal growth until reaching $\mathrm{pH} 2$.
TABLE III: MAXIMUM LOGARITHMIC CYCLES REACHED BY Saccharomyces Boulardii AFTER CHALLENGE UNDER DIFFERENT CONDITIONS OF TEMPERATURE, PH AND SALINITY

\begin{tabular}{|c|c|}
\hline Condition & Log cycles/mL \\
\hline \multicolumn{2}{|c|}{ Temperature/48hours } \\
\hline Initial & 2.88 \\
\hline $25^{\circ} \mathrm{C}$ & 7.75 \\
\hline $28^{\circ} \mathrm{C}$ & 7.62 \\
\hline $35^{\circ} \mathrm{C}$ & 8.64 \\
\hline $37^{\circ} \mathrm{C}$ & 7.63 \\
\hline Salinity/24hours & ----------- \\
\hline $1 \%$ & 7.25 \\
\hline $1.5 \%$ & 7.23 \\
\hline $2 \%$ & 6.89 \\
\hline $2.5 \%$ & 6.70 \\
\hline $3 \%$ & 6.62 \\
\hline $\mathrm{pH} / 72$ hours & ------------ \\
\hline 1.5 & 6.68 \\
\hline 2 & 6.88 \\
\hline 2,5 & 7.30 \\
\hline 3 & 7.63 \\
\hline 3.5 & 7.82 \\
\hline 4 & 6.77 \\
\hline 4.5 & 7.74 \\
\hline
\end{tabular}

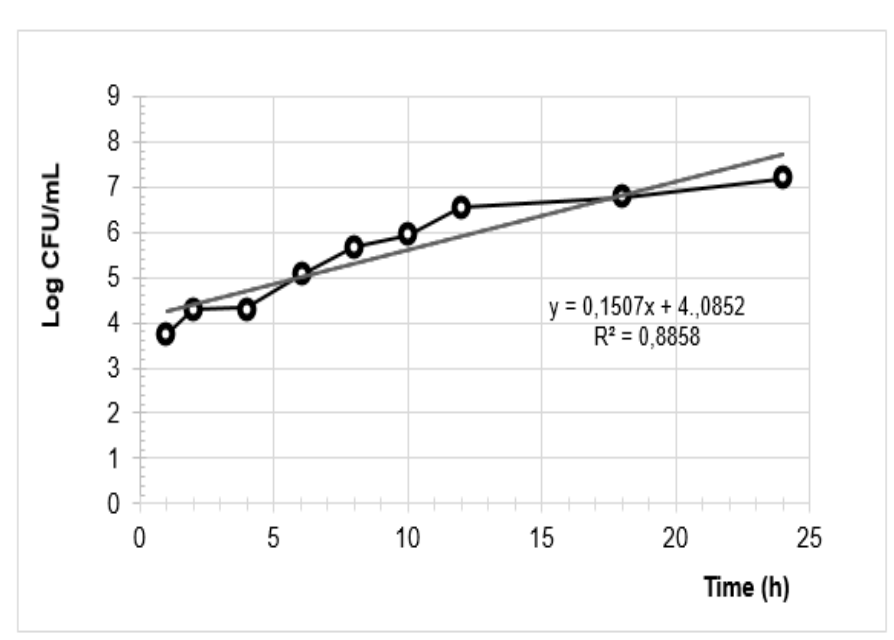

Fig. 1. Growth curve of Saccharomyces boulardii at $25^{\circ} \mathrm{C} / 24$ hours of in Yeast Extract broth and Glucose under agitation at $200 \mathrm{rpm}$. Reading of optical density at $\lambda 600 \mathrm{~nm}$ and colonies forming units $(\mathrm{CFU}) / \mathrm{mL}$ count by spread plate in YE agar plates after 72 hours $/ 25^{\circ} \mathrm{C}$.

\section{B. Microencapsulation}

In relation to microencapsulation methods, the methodology 1 by using culture in YEG broth was efficient, but dehydration occurred during the storage process. The microcapsules were reduced in size even when stored in distilled water and YEG broth (1: 1). A similar result of microcapsule deterioration was observed by [18] when using calcium alginate, where the microspheres deteriorated in about 30 days. Besides that, the process of obtaining microspheres with fresh culture is time-consuming and is not economically viable for industrial application. 
For methodology 2, it was used lyophilized yeast culture surrounded by a layer of chitosan, being the most efficient technique in protection. Likewise, [23] performed microencapsulation of prebiotic and probiotic cultures in alginate and chitosan capsules and found that the combination of protected even more against some exogenous factors. Although according to [39], chitosan is widely used in the food industry due to its antifungal action, here in our study, contamination by fungi, despite the imposed aseptic conditions, made this methodology unfeasible. Thus, the quality and homogeneity of production inputs is an objective to be achieved.

In relation to the methodology 3 , microencapsulation was performed with lyophilized culture of $S$. boulardii with a higher concentration, obtaining the best result in microcapsules for application in pet snack, by using only $2 \%$ sodium alginate and $0.1 \mathrm{M} \mathrm{CaCl}_{2}$. The capsules, measuring $1.5 \mathrm{~cm}$ in diameter, proved to be inert during the storage period, showing no deterioration, besides they were free from contamination, Likewise, [37] performed the encapsulation of Lactobacillus casei with sodium alginate coating, claiming that alginate protection was highly efficient in acid $\mathrm{pH}$ tests, bile salts and heat treatment.

\section{Evaluation Of Simulated Gastric And Intestinal} Juice Action On Microencapsulated Saccharomyces Boulardii

The results indicated that although there was a release (loss) of cells during the process of passing through gastric juice ( $\mathrm{pH} 2.0$ ), corresponding to $2.54 \mathrm{Log}$ cycles of colonies grown on SD agar plates (Fig. 2), with the intestinal juice the result was 5.92 Log cycles (Fig. 3).

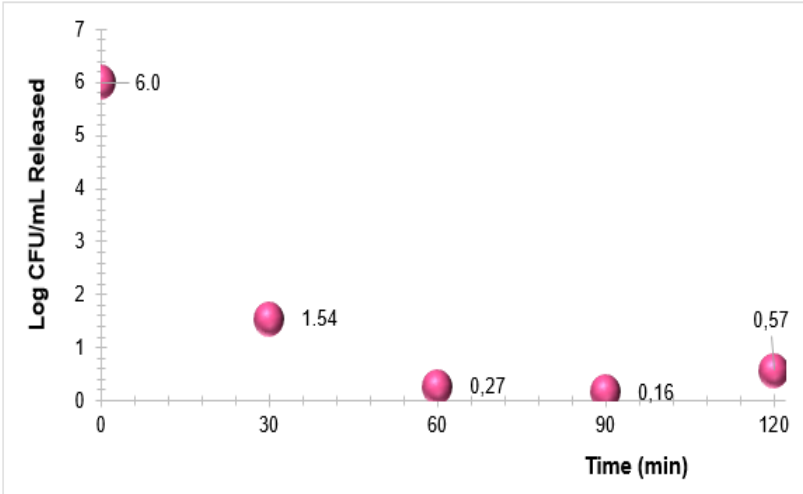

Fig. 2. Encapsulated Saccharomyces boulardii subjected to in vitro action of gastric juice ( $\mathrm{pH} 2.0)$. Results based on yeast release and growth on Sabouraud Dextrose agar plates at $25^{\circ} \mathrm{C} / 24$ hours.

Although the amount of microencapsulated yeasts resulting after passing through gastric juice was estimated to be just over 3 Log cycles, the final release of yeasts in the intestinal juice corresponded to 6 Log cycles. Therefore, the action of the intestinal juice allowed the total release yeasts.

Alginate when used as an encapsulating agent, especially sodium alginate, is insoluble in some organic solvents and in acidic media, with a $\mathrm{pH}$ below 3 [9]. However, in the present study, microencapsulated yeast cells were partially released during the action of gastric juice $(\mathrm{pH} 2.0)$, indicating that some change in the structure of the microcapsule occurred.

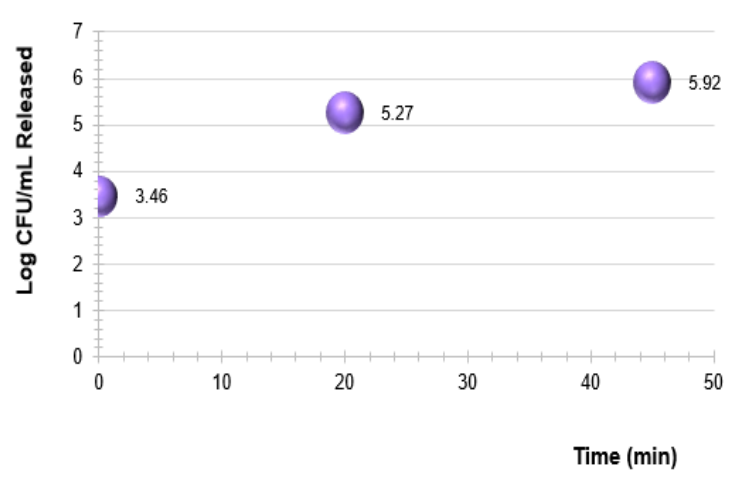

Fig. 3. Encapsulated Saccharomyces boulardii subjected to in vitro action of intestinal juice $(\mathrm{pH} 8.0)$ right after the action of gastric juice at $\mathrm{pH} 2.0$. Results based on release and growth on Sabouraud Dextrose agar plates at $25^{\circ} \mathrm{C} / 24$ hours.

The survival of probiotic microorganisms during passage in the gastrointestinal system, resisting low $\mathrm{pH}$, digestive enzymes, and bile salts, was maintained by the microencapsulation process, allowing the probiotic action of the microorganism, as recommended by the [28].

Therefore, it was estimated at about $4.18 \times 106 \mathrm{CFU}$ the total viable colonies in the animal's intestine, taking into account the 15 microcapsules into snack pet with meat pork, however already considering a loss of $2.54 \mathrm{Log}$ cycles during the process.

The shelf-life of the trachea snack with probiotic followed for 150 days. The pathogens Salmonella sp./25g and Clostridium sulphite reducing were not detected, so the product did not present a risk to the health of the animals (Table IV). In relation to the probiotic in the trachea snack, it resulted in $3.08 \mathrm{Log}$ cycles in the last month, a reduction of approximately $3 \mathrm{Log}$ cycles in the period of the final month. But, even with this loss it can still be considered viable and with probiotic potential. Given this result, the shelf life was defined at 120 days. S. boulardii presented an average of $5.62 \mathrm{Log}$ cycles, so there is a safety margin in the product and a guarantee of benefits provided by the indicated amount of probiotic to be ingested. Ideal for probiotic products is an initial density of $10^{8}$ to $10^{9}$ CFU/day which must be ingest for functional effects [53]. However, lower values at the product are accepted if their effectiveness is proven [15].

Comparing the count of molds and yeasts obtained from the trachea with probiotic and that obtained from the trachea without probiotic, the result was 2 more Log cycles of difference in the first due to the presence of $S$. boulardii. Molds and yeasts are widely distributed in the environment and can be found in the air and in food, which are an important source of contamination.

The trachea snack used here is an edible by-product containing MSM-based filling. But, in handling this type of by-product, contamination by mesophilic bacteria, molds and yeasts is a risk to be considered. The presence of probiotic yeast in trachea snack can contribute to reduce that risk. In view of the possible susceptibilities of the immune system of $\operatorname{dog}$ s and cats to inflammatory bowel disease [22] the continuous use of this yeast helps in the better quality of life of the animal, which is directly linked to its health. 
TABLE IV: MicrobIOLOGICAL ANALYSIS OF TRACHEA SNACK ADDED OF Saccharomyces boulardii

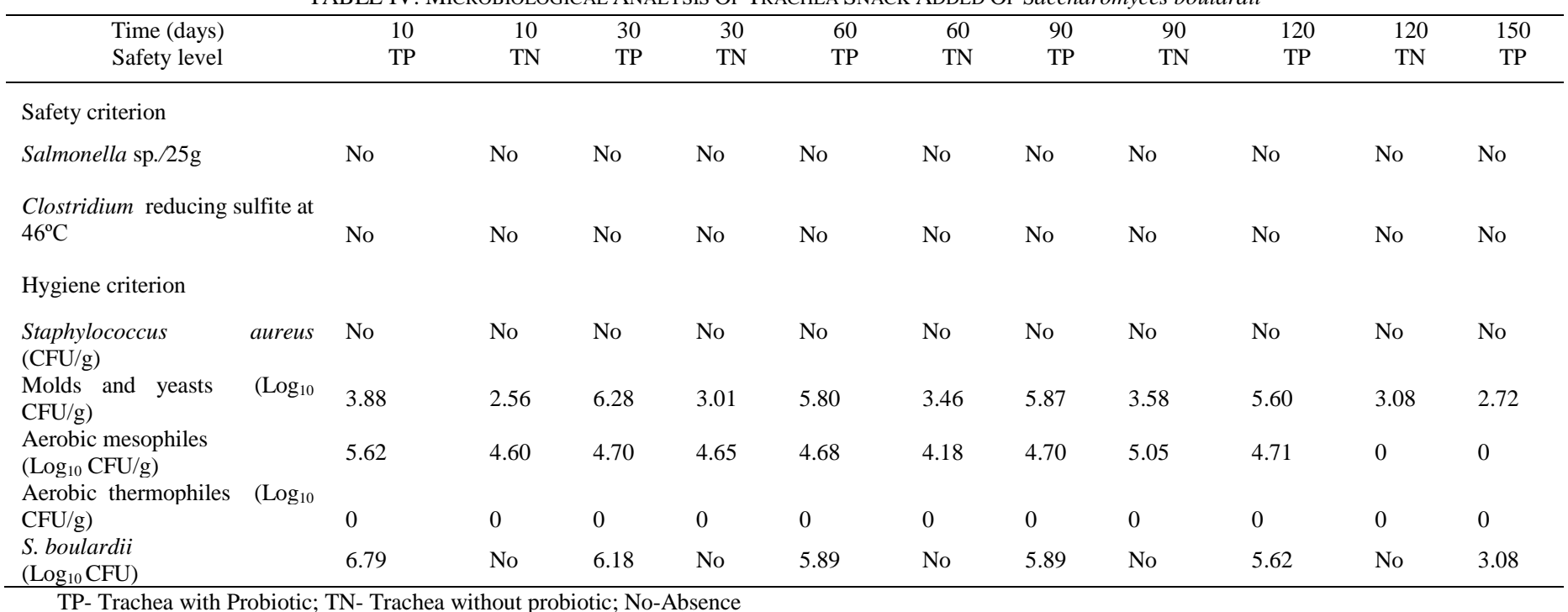

TP- Trachea with Probiotic; TN- Trachea without probiotic; No-Absence

\section{Physical And Chemical Analysis}

The trachea snack is a specific food, considered not complete in nutritional terms. In Table $\mathrm{V}$ the reference is made to complete foods according to the identity standards of the food products of the Ministry of Agriculture, livestock and supply in Brazil [13] Therefore, in relation to pet food, they must present on their labels or packaging, at least, the following guarantees: (maximum); crude protein (minimum); ethereal extract (minimum); fibrous matter (maximum); mineral matter (maximum), Calcium (maximum) and Calcium (minimum), and Phosphorus (minimum). Thus, Table V compares the physical-chemical composition of the stuffed trachea without probiotic with the stuffed trachea with probiotic with reference to the guarantee levels for a complete food for adult dogs.

TABLE V: COMPARISON OF THE RESUlts Of THE GuARANTEE LEVELS

For STUFFED TRACHEA SNACK Without PROBiotic Saccharomyces Boulardii AND SNACK With PROBIOTIC WITH THE IDENTITY STANDARDS OF FOOD PRODUCTS

\begin{tabular}{cccc}
\hline $\begin{array}{c}\text { Dry food } \\
\text { Warranty levels } \\
(\%)\end{array}$ & $\begin{array}{c}\text { For adult } \\
\text { dogs** } \\
\text { Official } \\
\text { standards }\end{array}$ & $\begin{array}{c}\text { stuffed trachea } \\
\text { snack- no } \\
\text { probiotic }\end{array}$ & $\begin{array}{c}\text { stuffed trachea } \\
\text { snack with } \\
\text { probiotic }\end{array}$ \\
\hline $\begin{array}{c}\text { Humidity (max.) } \\
\text { 22/5000 }\end{array}$ & 12 & 25,40 & 17,90 \\
$\begin{array}{c}\text { Crude protein } \\
\text { (min.) }\end{array}$ & 16 & 36,10 & 57,50 \\
$\begin{array}{c}\text { Ethereal extract } \\
\text { (min.) }\end{array}$ & 4,5 & & \\
$\begin{array}{c}\text { Fibrous matter } \\
\text { (max.) }\end{array}$ & 6,5 & 6,55 & 11,44 \\
$\begin{array}{c}\text { Mineral material } \\
\text { (max.) }\end{array}$ & 12 & 0,11 & 0,78 \\
$\begin{array}{c}\text { Calcium (max.) } \\
\text { Phosphor (min.) }\end{array}$ & 2,4 & 3,13 & 2,56 \\
\hline$* * 13]$ & 0,6 & 1,56 & 1,83 \\
\end{tabular}

$* *[13]$

The values presented are well accepted, including representing a final product with excellent protein value. The addition of salt concentration interferes with a small decrease in the tolerance of microorganisms, but still with good results. Therefore, in the comparison between stuffed trachea without probiotic and stuffed trachea with probiotic on the minimum level of phosphorus. The first one presented $0.08 \%$ below the limit for complete foods. For humidity both types of trachea snacks were above the limit for dry product as mentioned in the ordinance above. The Fig. 4 summarizes final data obtained for stuffed trachea snack with probiotic. Except for mineral material, the trachea snack with probiotic showed the highest levels for protein, ether extract, fibers, calcium, and phosphorus. This is since yeast is constituted on average by $48.2 \%$ total dietary fiber ( $43.7 \%$ insoluble fiber and $4.5 \%$ soluble fiber); $7.9 \%$ crude protein and $19.8 \%$ ethereal extract [43].

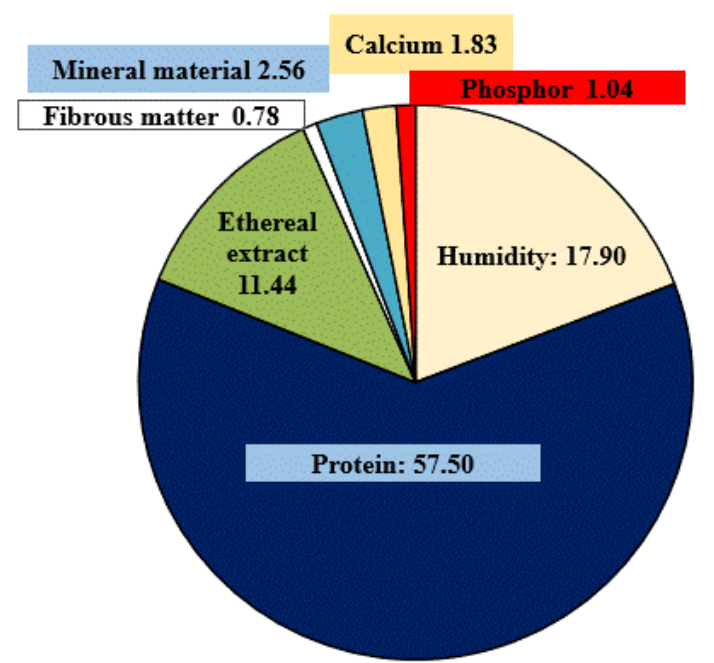

Fig. 4. Percentual levels of mineral material, fibers, calcium, phosphorus and other in stuffed trachea snack with probiotic Saccharomyces boulardii.

The yeasts are sources of unicellular protein and B vitamins, enzymes, volatile fatty acids, chelated minerals, among others, which provide better performance, greater resistance, and less stress to the animal [17]. The chemical composition depends on a series of factors, such as the nature of the substrate used, degree of aeration of the medium, yeast species, treatments imposed on the culture medium and concentration of salts, among others. However, for a product to play a role on health, it is not enough that it has advantageous nutritional characteristics. It must reach the consumer, be a product with a favorable taste with attractive properties [7], [34]. 


\section{E. Palatability}

When developing a new product, one of the fundamental points is the evaluation of its acceptability to predict the behavior towards the consumer market [45].

The palatability of the food is determined by the association of chemical and physical aspects, based on odor, texture, size, temperature, and flavor. Being able to relate the canine preferences with that of the owners, as well as the physical and social environment in which the dogs find themselves [51].

In the present study, acceptability was tested with 20 animals. Average scores were obtained by race (Fig. 5). Among the animals, the Poodle breed was the only one who disliked the product. Details about this breed provided by the veterinarian who accompanied the test indicated that it has a higher requirement in the selection of its foods compared to other breeds, which may be the reason for the low average.

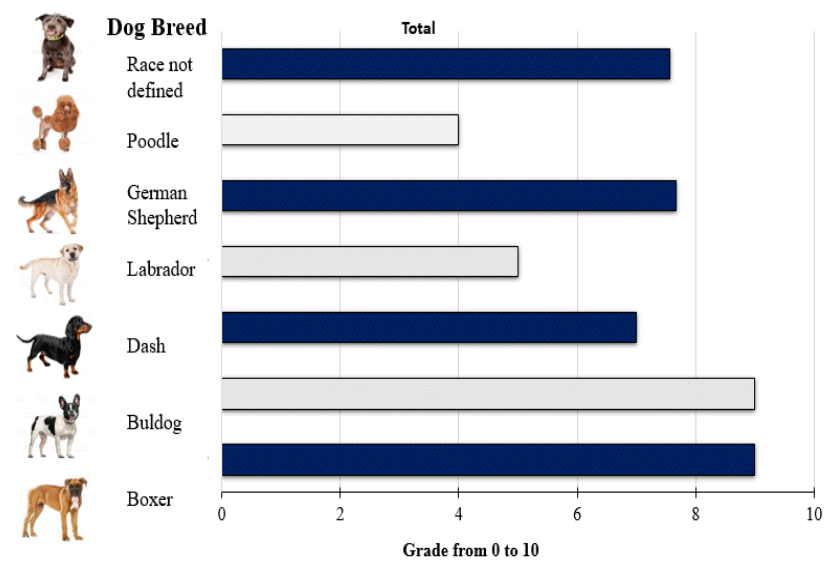

Fig. 5. Average degrees of reaction of dogs by the palatability test for trachea snack stuffed with meat and added of probiotic.

According to [51] canine preferences can relate to that of the owners, as well as the physical and social environment in which the dogs find themselves. In addition, they consider other factors that can influence the perception of odours such as: race, sex, environment, and medication administration are the most important.

In the present study the average age of dogs was 5.4 years. Comparing between genders, the female had greater acceptance, with a difference of 2.2 points. Only one dog was on medication, but this factor had no influence on the animal response.

According to [57] and [26], for the product to be considered as accepted, in terms of its sensory properties, it is necessary that it obtains an Acceptability Index (AI) of at least $70 \%$. Based on the grades for acceptability and AI calculation (equation 2), the product presented $\mathrm{AI}$ in $77.8 \%$ considered to be of good palatability.

Comparing with work involving the incorporation of encapsulated probiotic microorganisms for human food, [32] observed, in yogurt, that the calcium alginate capsules were visible and perceptible in the mouth when ingested, causing the product to be rejected by the tasters. However, for use in cereal bars, the incorporation of microorganisms occurred without them being able to be sensorially detected [5].
The palatability of the snack for dogs was found to be positive, as there was no leftover food offered to the taster dogs, characterizing that the presence of the microcapsules did not influence the feeding.

Based on the data obtained, it can be considered that the yeast with probiotic potential Saccharomyces boulardii developed its greatest growth at $25^{\circ} \mathrm{C}$. The microencapsulation methodology adapted for lyophilized yeast (methodology 3) was more efficient, avoiding the greatest loss of cells. In addition, the microcapsules remained viable during the simulation of the action in the simulated gastrointestinal transit, with greater release of cells in the intestinal juice, this will allow their effectiveness (survival and viability) in real conditions.

\section{ACKNOWLEDGMENT}

The authors would like to thank to the technicians from the University's Biotechnology Center.

\section{FINANCIAL SUPPORT}

Coordination for the Improvement of Higher Education Personnel - Brazil (CAPES) - Financing Code 001, and National Council for Scientific and Technological Development (CNPq) Brazil.

\section{REFERENCES}

[1] Abinpet. (2019). Mercado pet Brasil. São Paulo: Associação brasileira da indústria de produtos para alimentação de animais de estimação. [Online]. Available: http://abinpet.org.br/mercado/\#.

[2] M. S. Alves, "Microencapsulação de bactérias lácticas com potencial probiótico para produção de pasta de azeitona," Dissertation, Universidade Nova de Lisboa, 2013.

[3] K. P. Aptekmann, et al., "Aspectos nutricionais e ambientais da obesidade canina," Ciência Rural, vol. 44, no. 11, pp. 2039-2044, Nov 2014.

[4] S. Arslan, M. Erbas, I. Tontul, and A. Topuz, "Microencapsulation of probiotic Saccharomyces cerevisiae var. boulardii with different wall materials by spray drying," LWT-Food Science and Technology, vol. 63, no. 1, pp. 685-690, Mar 2015.

[5] G. A. Bastos, E. M. Paulo, and A. C. N. Chiaradia, "Aceitabilidade de barra de cereais potencialmente probiótica," Braz. J. Food Technol., vol. 17, no. 2, pp. 113-120, Apr/June 2014.

[6] C. G. Batista, et al., "Desempenho e saúde de bezerras alimentadas com leite sem resíduo de drogas antimicrobianas ou leite de vacas tratadas contra mastite adicionado ou não de probiótico," Arq. Bras. Med. Vet. Zoot., vol. 60, no. 1, pp. 185-191, Feb 2008.

[7] J. H. Behrens, S. M. Roig, and M. A. A. P. Silva, "Fermentation of soymilk by commercial lactic cultures: development of a product with market potential," Acta Alimentaria, vol. 33, no. 2, pp. 101-109, 2004.

[8] P. Bermudes, "Tendências de mercado e perfil do consumidor," presented at the XV Congresso CBNA PET, Expo D. Pedro, Campinas, São Paulo, Apr 2016.

[9] A. C. K. Bierhalz, "Desenvolvimento de biofilmes de alginato impregnados com natamicina e aferição de seu potencial antimicótico," Ph.D thesis, Universidade Estadual De Campinas, Campinas, 2014.

[10] F. M. Borges, R. M. Salgarello, and Gurian, T.M., "Recentes avanços na nutrição de cães e gatos," presented at the $2^{\circ}$ Simpósio sobre nutrição de animais de estimação, Campinas, Mar 2003.

[11] Ministry of Agriculture, Livestock and Supply, Laboratory of Animal Products / SLAV, Brazil. Determination of calcium in animal products by oxymetry. Available: https://www.gov.br/agricultura/ptbr/assuntos/laboratorios/legislacoes-e-metodos/arquivos-metodos-daarea-poa-iqa/met-poa-slav-32-02-determinacao-de-calcio.pdf

[12] National Health Surveillance Agency, Brazil. Provides the need for constant improvement of health control actions in the area of food, aiming at protecting the health of the population and regulating the microbiological standards for food. 2001. Available: 
http://portal.anvisa.gov.br/documents/33880/2568070/RDC_12_2001. pdf/15ffddf6-3767-4527-bfac-740a0400829b.

[13] Ministry of Agriculture, Livestock and Supply, Brazil. Establish criteria and procedures for the registration of products, for labelling and advertising and for exemption from the obligation to register products intended for feeding pet animals. 2001. Available: file:///C:/Users/Usu\%C3\%A1rio/Downloads/Resolu\%C3\%A7\%C3\% A3o\%20RDC\%20n\%C2\%BA\%2012,\%20de $\% 2002 \% 20$ de $\% 20$ janeiro $\% 20$ de $\% 202001 \% 20(1)$.pdf.

[14] Ministry of Agriculture, Livestock and Supply, Brazil. Manual of official methods for analyzing food of animal origin. 2019. Available: https://www.gov.br/agricultura/pt-br/assuntos/laboratorios/legislacoese-metodos/arquivos-metodos-da-area-poa-

iqa/ManualdeMtodosOficiaisparaAnlisedeAlimentosdeOrigemAnimal 2ed.pdf

[15] National Health Surveillance Agency, Brazil. Provides for the requirements for proving the safety and health benefits of probiotics for use in food. 2018. Available: http://pesquisa.in.gov.br/imprensa/jsp/visualiza/index.jsp?data=27/07/ 2018\&jornal $=515 \&$ pagina $=100$

[16] Ministry of Agriculture, Livestock and Supply, Brazil. Provides for the mandatory inspection and inspection of products intended for animal feed, Brazil. $2007 . \quad$ Available: https://www.gov.br/agricultura/pt-br/assuntos/insumosagropecuarios/insumos-pecuarios/alimentacao-animal/arquivosalimentacao-animal/legislacao/decreto-no-6-296-de-11-de-dezembrode-2007.pdf

[17] J. E. Butolo, Qualidade de Ingredientes na alimentação animal. 2nd ed. Campinas: Colégio Brasileiro de Nutrição Animal, 2010.

[18] E. Callone, R. Campostrini, G. Carturan, A. Cavazza, and R. Guzzon, "Immobilization of yeast and bacteria cells in alginate microbeads coated with silica membranes: procedures, physico-chemical features and bioactivity," Journal of materials chemistry, vol. 18, no. 40, pp. 4839-4848, July 2008.

[19] S. Cappelli, E. Manica, and J. H. Hashimoto, "Importância dos aditivos na alimentação de cães e gatos: Revisão," PUBVET, vol. 10, no. 3, pp. 212-223, Mar 2016

[20] A. Carciofi. 2017. Fisiologia digestiva de cães e gatos - introdução [Online]. Universidade Estadual de São Paulo. Available: http://www.fcav.unesp.br/Home/departamentos/clinicacv/AULUSCA VALIERICARCIOFI/fisiologia-digestiva-caes-e-gatos-2017resumido.pdf.

[21] E. L. Carmo, R. V. B. Fernandes, and S. V. Borges, "Microencapsulação por spray drying, novos biopolímeros e aplicações na tecnologia de alimentos," Journal of Chemical Engineering and Chemistry, vol. 1, no. 2, pp. 30-44, 2015.

[22] C. M. Cascon, M. F. V. Mello, J. S. Leite, and A. M. R. Ferreira, "Avaliação clínica, endoscópica e histopatológica de cães com doença inflamatória intestinal," Pesquisa Veterinária Brasileira, vol. 37, no 11, pp. 1287-1291, Nov 2017

[23] M. Chávarri, et al., "Microencapsulation of a probiotic and prebiotic in alginate-chitosan capsules improves survival in simulated gastrointestinal conditions," International Journal of Food Microbiology, vol. 142, pp. 185-189, June 2010

[24] D. Czerucka, T. Piche, and P. Rampal, "Yeast as probiotics Saccharomyces boulardii," Alimentary pharmacology \& therapeutics, vol. 26, no. 6, pp. 767-778, July 2007

[25] E. C. Dinleyici, M. Eren, M. Ozen, Z. A. Yargic, and Y. Vandenplas. (February 2012). Effectiveness and safety of Saccharomyces boulardii for acute infectious diarrhea. Journal Expert Opinion on Biological Therapy. [Online]. 12(4). pp. 395-410. Available: https://www.tandfonline.com/doi/full/10.1517/14712598.2012.664129

[26] S. D. Dutcosky, Análise sensorial de alimentos, 3rd ed., Curitiba: Champagnat, 2011.

[27] [27] L. Edwards-Ingram, et al., "Genotypic and physiological characterization of Saccharomyces boulardii, the probiotic strain of Saccharomyces cerevisiae," Applied and Environmental Microbiology, vol. 73 , no. 8, pp. 2458-2467, Apr 2007

[28] Fao, 2001 "Health and nutritional properties of probiotics in food including powder milk with live lactic acid bacteria," Prevention, 5 (1), $1-10$.

[29] C. S. Favaro-Trindade. "Microencapsulação de probióticos," in Probióticos e prebióticos em alimentos, Suzana M.I. Saad, Adriano G. da Cruz and José de Assis F. Faria, eds.. Livraria Varela, SP, 2011, p. $239-254$

[30] S. Feizizadeh, A. Salehi-Abargouei, and V. Akbari, "Efficacy and safety of Saccharomyces boulardii for acute diarrhea," Pediatrics, vol 134, no. 1, pp. 176-191, June 2014.
[31] J. L. R. Fietto, et al., "Molecular and physiological comparisons between Saccharomyces cerevisiae and Saccharomyces boulardii," Can. J. Microbio., vol. 50, no. 8, pp. 615-621, May 2004.

[32] G. N. Godward, "Studies on enhancing the viability and survival of probiotic bacteria in dairy foods through strain selection and microencapsulation," dissertation, University of Western Sydney, 2000.

[33] S. Guandalini, "Probiotics for prevention and treatment of diarrhea," Journal of clinical gastroenterology, vol. 45, no. 3, pp. 149153, Nov/Dec 2011.

[34] C. N. Heenan, M. C. Adams, R. W. Hosken, and G. H. Fleet, "Survival and sensory acceptability of probioticmicroorganisms in a nonfermented frozen vegetarian dessert," LWT-Food Science and Technology, vol. 37, no. 4, pp. 461-466, 2004

[35] Instituto Adolfo Lutz, Métodos físico-químicos para análise de alimentos, 4th ed. São Paulo: Instituto Adolfo Lutz, 2008.

[36] Y. K. Lee, and S. Salminen, Handbook of Probiotics and Prebiotics, 2nd ed. Nova Jersey: John Wiley \& Sons, 2009.

[37] S. Mandal, A. K. Puniya, and K. Singh, "Effect of alginate concentrations on survival of microencapsulated Lactobacillus casei NCDC-298," International Dairy Journal, vol. 16, no. 10, pp. 11901195, 2006.

[38] MarketResearch.com, International Pet Market Perspectives: Trends and Opportunities in Pet Food - 2019.

[39] G. M. Matté, and S. Rosa, "A tecnologia da microencapsulação através das microesferas de quitosana," Revista Iberoamericana de Polímeros, vol. 14, no. 5, pp. 206-218, Sep 2013.

[40] M. S. Mazon, and W. G. Moura, "Cachorros e humanos: Mercado de rações pet em perspectiva sociológica," Civitas, vol. 17, no. 1, pp 138-158, Jan/Apr 2017

[41] L. V. Mcfarland, "Systematic review and meta-analysis of Saccharomyces boulardii adult patients," World Journal Gastroenterology, vol. 16, no. 18, pp. 2202-2222, May 2010.

[42] C. R. Menezes, et al., "Microencapsulação de probióticos: avanços e perspectivas," Ciência Rural, vol. 43, no. 7, pp. 1309-1316, July 2013

[43] I. S. Middelbos, M. R. Godoy, N. D. Fastinger, and G. C. Fahey Jr, "A dose-response evaluation of spray dried yeast cell wall supplementation of diets fed to adult dogs: Effects on nutrient digestibility, immune indices and fecal microbial populations," Journal of Animal Science, vol. 85, no. 11, pp. 3022-3032, July 2007.

[44] E. Migowski, and B. S. Pugliese, "Gastrenterite aguda: por que dose maior de Saccharomyces boulardii na fase aguda," Revista Brasileira de Clininica Médica, vol. 7, pp. 267-271, July 2009.

[45] J. A. Moscatto, S. H Prudêncio-Ferreira, and M. C. O. Hauly, "Farinh de yacon e inulina como ingredientes na formulação de bolo de chocolate," Ciência e Tecnologia de Alimentos, vol. 24, no. 4, pp. 634640, Oct/Dec 2004..

[46] B. L. Nadai, "Efeito da suplementação de nutrientes e da concentração de permeado de soro de leite no crescimento de Saccharomyces boulardii em sistema descontínuo" dissertation, Universidade Estadual do Oeste do Paraná, Toledo, PR, 2015.

[47] A. I. Nagashima, P. E. Pansiera, M. M. Baracat, and R. J. H. C. Gómez, "Development of effervescent products, in powder and tablet form, supplemented with probiotics Lactobacillus acidophilus and Saccharomyces boulardii," Food Science and Technology, vol. 33, no. 4, pp. 605-611, Oct/Dec 2013

[48] M. N. Oliveira, Tecnologia de produtos lácteos funcionais, São Paulo: Atheneu, 2009

[49] Y. P. Peuckert, V. B. Viera, L. H. R. Hecktheuer, C. T. Marques, an C. S. Rosa, "Caracterização e aceitabilidade de barras de cereais adicionadas de proteína texturizada de soja e camu-camu (Myrciaria dubia)," Alimentos e Nutrição, vol. 21, no. 1, pp. 147-152, jan/mar 2010.

[50] C. Pothoulakis, "Anti-inflammatory mechanisms of action of Saccharomyces boulardii," Alimentary pharmacology \& therapeutics, vol. 30 , no. 8 , pp, 826-833, July 2009.

[51] D. A. Pizzato, and J. L. Domingues. (March/April 2008) Palatabilidade de alimentos para cães. Revista Eletrônica Nutritime. [Online]. 5(2). pp. 504-511. Available: http://nutritime.com.br/arquivos_internos/artigosBK/051V5N2P504_5 11_MAR2008.pdf

[52] S. M. I. Saad, "Probióticos e prebióticos: o estado da arte," Revista Brasileira de Ciências Farmacêuticas, vol. 42, no. 1, Jan/Mar 2006.

[53] Saad, S.M.I., et al. "Probióticos em alimentos: aspectos tecnológicos, legislação e segurança no uso". In: Probióticos e prebióticos em alimentos, Suzana M.I. Saad, Adriano G. da Cruz and José de Assis F. Faria, eds.. Livraria Varela, SP, 2011, pp. 23-50.

[54] T. T. Santos, and M. A. Varavallo, "A importância de probióticos para o controle e/ou reestruturação da microbiota intestinal," Revista cientifica do ITPAC, vol. 4, no. 1, pp. 40-49, Jan 2011. 
[55] Sebrae, Estudo de Tendências de Mercado, 2nd. ed. Salvador: Sebrae, 2013.

[56] A. Tannis, Probiotic Rescue: how you can use probiotics to fight cholesterol, cancer, superbugs, digestive complaints and more, 1st ed. Canada: John Wiley \& Sons, 2008.

[57] E. Teixeira, E. M. Menert, and P. A. Barberta, Análise sensorial de alimentos, Florianópolis: UFSC, 1987.

[58] M. B. Thomas, M. Vaidyanathan, K. Radhakrishnan, and A. M. Raichur, "Enhanced viability of probiotic Saccharomyces boulardii encapsulated by layer-by-layer approach in $\mathrm{pH}$ responsive chitosandextran sulfate polyelectrolytes," Journal of Food and Engineering, vol. 136, pp.1-8, Mar 2014.

[59] Z. M. Tomičić, et al., "Beneficial properties of probiotic yeast Saccharomyces boulardii," Food and Feed Research, vol. 43, no. 2, pp. 103-110, 2016.

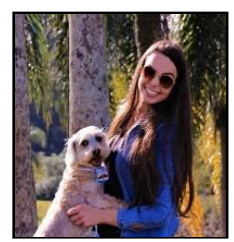

Sheila Baroncello is Bachelor in Food Engineering and Master in Science and Biotechnology by the University of West of Santa Catarina, Videira, Brazil.

She was awarded by the Research Foundation of the State of Santa Catarina (Fapesc) in the Synapse Innovation Program in biotechnology.

MSc. Baroncello currently develops and manages innovative projects in her pet food Company.

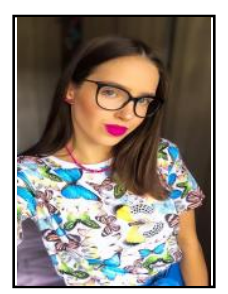

Nathalia T. Candiago is a bachelor student in Industrial Biotechnology at University of West of Santa Catarina, Videira, SC, Brazil

She is a beginning researcher in Biotechnology and has a $\mathrm{CNPq} /$ Brazil scholarship in Technology and Innovation. Currently, she develops research on new products with probiotics.

Ms. Candiago was awarded by $\mathrm{CNPq}$ for developing research on yeast microencapsulation with application in feed products.

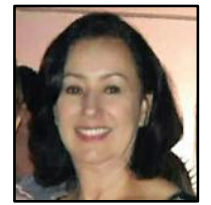

Jane Mary L. N. Gelinski is Bachelor in Biological Sciences by Federal University of Pernambuco and PhD in Food Sciences by São Paulo University, Brazil.

She was professor and research fellowship advisor at Unoesc, Videira, SC, Brazil until 2019 while developed many projects in Biotechnology.

Dr. Gelinski currently develops studies in food sciences and contributes as scientific reviewer for several national and international journals for her expertise in microbiology.

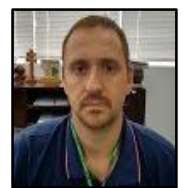

Vinícius Caliari is an Industrial Chemist, and $\mathrm{PhD}$ in Food Sciences by Federal University of Santa Catarina, Brazil.

$\mathrm{He}$ is researcher at Videira Experimental Station, SC, Brazil. $\mathrm{He}$ is also professor and student adviser at University of West of Santa Catarina, Videira, Brazil. Dr. Caliari currently develops research in food and beverage sciences, especially in the development and quality control of sparkling wines.

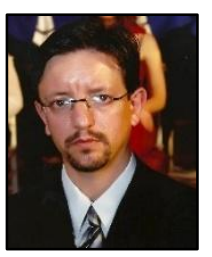

César Milton Baratto is Bachelor in Biological Sciences, and $\mathrm{PhD}$ in Cellular and Molecular Biology by the Federal University of Rio Grande do Sul-UFRGS, Brazil. $\mathrm{He}$ is professor and coordinator of the Bachelor's degree in Industrial Biotechnology at University of West of Santa Catarina, Videira, SC, Brazil.

Dr. Baratto currently develops research in molecular genetics of microorganisms and hydrolytic enzymes. 